Ethiopian Journal of Environmental Studies \& Management 10(3): 378 - 388, 2017.

ISSN:1998-0507

doi: https://dx.doi.org/10.4314/ejesm.v10i3.8

Submitted: January 04, 2016

Accepted: May 01, 2017

\title{
AN ASSESSMENT OF SEASONAL VARIATIONS IN PHYSICO-CHEMICAL CHARACTERISTICS OF UNDERGROUND WATER IN A GROWING TROPICAL CITY IN NIGERIA
}

*OGUNBODE, T.0., ${ }^{1}$ AKINTUNDE, E.A. ${ }^{2}$ AND AKINOLA, 0.T. ${ }^{3}$

${ }^{1}$ Faculty of Basic Medical and Health Sciences, Bowen University, Iwo Nigeria

${ }^{2}$ Department of Chemistry and Industrial Chemistry, Bowen University, Iwo, Nigeria

${ }^{3}$ Department of Biological Sciences, Bowen University, Iwo, Nigeria

\begin{abstract}
The quality of underground water is influenced by natural and anthropological factors which need to be constantly monitored in order to safeguard human health. This work investigated seasonal variations in well water in Iwo town, Osun State Nigeria. A total of 15 water samples were collected from hand-dug wells from each of the political wards. Samples were analysed for seven physico-chemical parameters namely $\mathrm{pH}$, temperature, Electrical Conductivity, Phosphate, Sulphate, Nitrate and Total Hardness. The analysis was done according to standard method of water examination. The results of the analysis showed that the mean content of each of the parameters was higher during the dry season. These are respectively $8.10 \pm 0.61,28.55^{\circ} \mathrm{C} \pm 0.88,185.60 \mu^{\prime} \mathrm{cm}^{-1} \pm 80.88,0.04 \mathrm{mg} / \mathrm{L} \pm 0.02$, $0.05 \mathrm{mg} / \mathrm{L} \pm 0.02,0.02 \mathrm{mg} / \mathrm{L} \pm 0.01$ and $315.47 \mathrm{mg} / \mathrm{L} \pm 92.34$. These indicate that all water quality parameters analysed were within the WHO and NIS permissible limits. It implies that the well water in Iwo is generally safe for human consumption. However, efforts should be made for regular quality assessment, maintenance and prevention from surface wash into wells for better quality. Further investigation is suggested to examine the bacteriological contents of the underground water to ascertain that the water is free of bacteria to ensure its safety to human health.
\end{abstract}

Key Words: Domestic uses, Osun State, Seasonal variation, Well water, Water quality

\section{Introduction}

Accessibility to any water source especially for domestic uses is partly dependent on its quality status. For instance, hard water which is characterized by poor soap lathering is not likely to attract people for use in washing and bathing. In the same vein, the colour and the location of water may prevent a potential water user from accessing such a source for any given use/uses. Mark et al. (2002) had noted that the consumption of polluted water contributed to numerous health problems in the developing countries such as the one billion or more incidents of diarrhoea that occur annually. Similarly, Nash (1993) also observed that water-related diseases are a human tragedy, killing millions of people each year, preventing millions of people from enjoying a healthy living and undermining 
development efforts. United Nations (1997) reported that about 2.3 billion in the world suffer from diseases that are linked to water.

Even though both surface and subsurface water sources are available to man, apart from rainfall through which other sources are replenished, the latter has been considered better and safer for human consumption, especially in the rural communities (MacDonald, et al., 2005). Surface sources such as rivers, brooks and streams have been found to be susceptible to various pollutants. Unfortunately, the subsurface generally viewed to be of better quality has been reportedly found to be equally open to various pollutants. Ibe and Okplenye (2005) noted that the main origins of pollution of wells and boreholes are industrial, domestic and agricultural activities which they claimed could be continuous or accidental.

Despite this, the dependence on ground water in rural areas and also semi urban areas of sub-Saharan Africa is inevitable. Adelana (2005) attributed this fact to climate change and contaminations due to anthropological activities which limit the use of surface water resources. In another sense, exploitation of underground water for domestic uses is more preferred by most African governments by virtue of its cheapness, time cost and expertise required when compared to pipe-borne water facilities.

It has therefore become imperative that the quality status of subsurface water resources is constantly monitored in other to safeguard human health (Yakubu, 2013). This work examines the influence of seasonal variations on the integrity of underground water in Iwo, Osun State, Nigeria.

Study Area

This study was carried out in Iwo, the headquarters of Iwo Local Government Area (LGA) in Osun State, Nigeria (Fig. 1). Iwo covers an area of $245 \mathrm{~km}^{2}$ with a population of 191,348 according to 2006 population census (National Population Commission (NPC), 2006). It is located between the coordinates of $7^{\circ} 38^{\prime} \mathrm{N}$ and $4^{\circ} 11^{\prime} \mathrm{E}$. The town is divided into 4 quarters namely Gidigbo, Isale-Oba, Molete, Oke-Adan and Oke-Oba out of which 15 political wards were carved out. While Gidigbo, Molete and Oke-Adan has 3 wards each, Isale-Oba and Oke-Oba has 4 and 2 wards respectively. The popular Odo-Ori market attracts traders from within and outside the State. Iwo is also strategic because the railway tracks from Ibadan passes through the town which helps the commercial and economic development of Iwo and its suburb. 


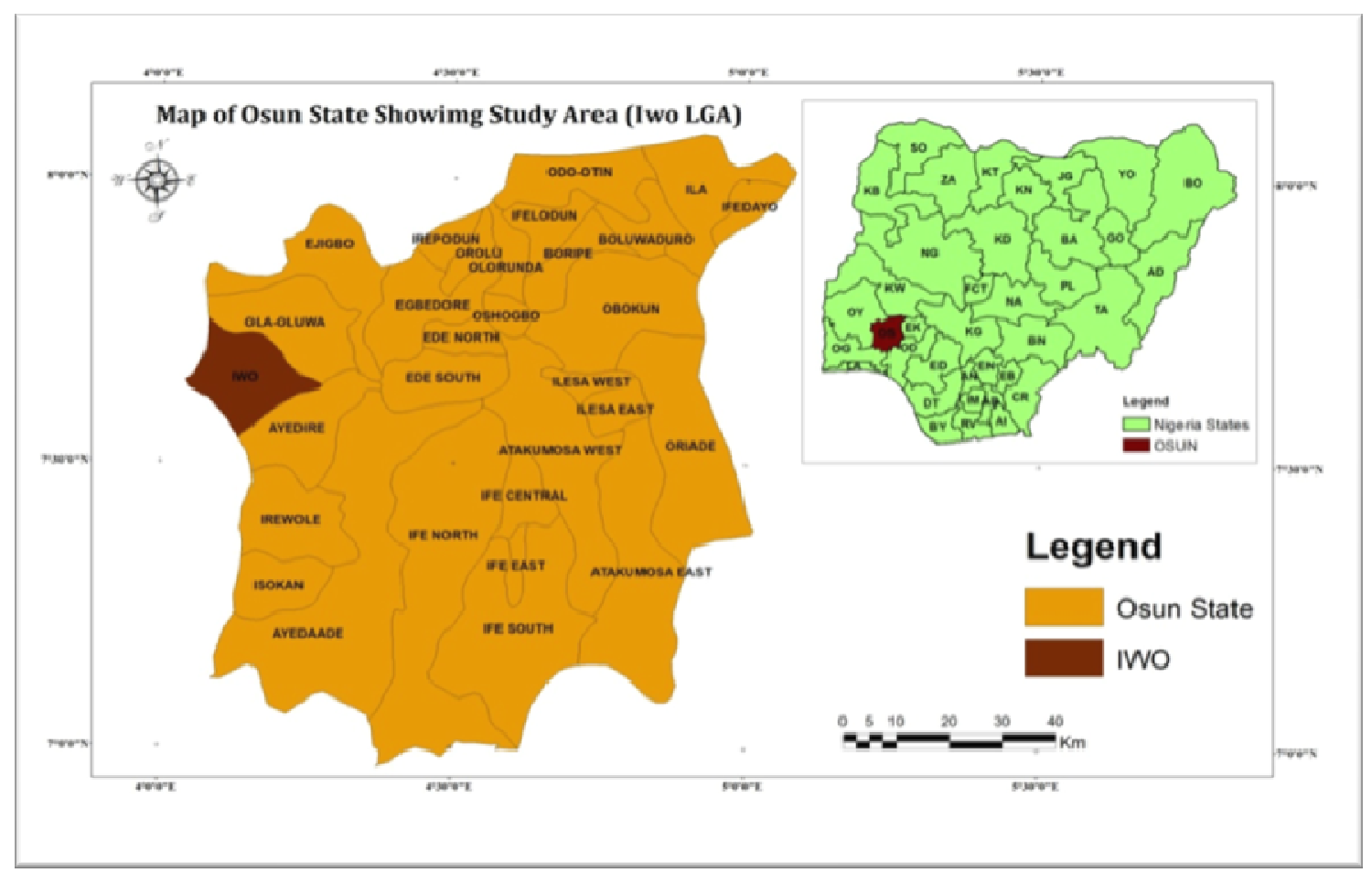

Fig. 1: Map of Osun State showing study area (Inset: Location of Osun State in Nigeria) (Source: GIS Production, 2013)

Iwo is underlain by Precambrian igneous and metamorphic rocks while the topography is generally undulating. Its agriculturally rich advantage makes it a major trading centre for cocoa, kolanuts, foodstuffs, meat and timber. The major source of potable water in Iwo is from Aiba Water Reservoir located within Government Forest Reservation Area in the town. This Water Works has not been able to discharge its responsibilities satisfactorily, the problem being attributed to poor management, poor maintenance culture, and corruption and also increase in the population of the area. Apart from this, Iwo is located in the tropical region with annual total rainfall of between $2000 \mathrm{~mm}$ and 3000 $\mathrm{mm}$ and high daily temperature of about $27^{\circ} \mathrm{C}$. The rainy season usually lasts eight months starting from March through
October while dry season sets in in November and ends in February. The people often harvest rainwater for home uses. This, however does not last last days because of the capacities of the storage facilities which include pots, kegs, buckets etc. This makes rainfall unreliable source for home use. However, the Aiba Dam which could have been more reliable in this regard is characterized with persistent erratic supply. Hence, the quest for other alternative which can prove reliable for domestic uses has led to the exploitation of underground sources in Iwo town. Almost every home and compound has a well apart from other ones provided by the government of different levels and other philanthropists especially the politicians, religious and socio-cultural groups. 


\section{Material and Methods Data Collection}

Water samples for rainy season were collected in August, 2013 when the rain is at its peak while those of dry season were collected in February, 2014 when the dryness is at its peak also. The samples were collected following the same procedure. A sample each was collected from each of the 15 wards in Iwo LGA for physico-chemical attributes. Samples were collected in $2 \mathrm{~L}$ plastic bottles that have been previously soaked in $10 \%$ nitric acid for $48 \mathrm{~h}$ and rinsed with distilled water. The containers were rinsed three times on the site with well water before collecting the water samples. The samples were stored in the refrigerator prior to analysis in order to ensure that the physical properties were maintained. The results of laboratory analysis were assessed and compared with the internationally acceptable standard.

\section{Determination of Physico-chemical} Parameters

All the reagents used were of analytical grade and the instruments were pre-calibrated appropriately prior to measurement. Eight parameters were analysed. These are $\mathrm{pH}$, Water temperature and electrical conductivity which were measured in-situ using Testr II dual range meter (Eutech instruments, Malaysia) after calibrating with standard buffer solution of 4 and 10; Sulphate, Phosphate and Nitrate and Total Hardness (TH) were determined by procedure described by Ademoroti (1996).

\section{Results and Discussion}

Tables 1 and 2 showed the physicochemical characteristics of the underground water during dry and wet seasons respectively in Iwo. The results revealed that there is generally disparities in the concentrations of quality parameters analysed for dry and wet seasons. The disparities in the seasonal concentrations of the quality parameters could have indicated the importance of underground water recharge through infiltration, seepage and percolation processes. These processes are more prominent during the rainy season and could be significant in the following ways: Firstly, they may induce heavy concentrations of the quality parameters in the well water studied and secondly, they may help in the dilution of the parameters thereby reducing their respective concentrations. 
Table 1: Physico-chemical quality of underground water in Iwo during dry season

\begin{tabular}{llllllllll}
\hline $\mathrm{S} / \mathrm{N}$ & $\begin{array}{l}\text { Name of } \\
\text { Quarters }\end{array}$ & WARD & $\mathrm{pH}$ & $\begin{array}{l}\mathrm{Temp} \\
\left({ }^{\circ} \mathrm{C}\right)\end{array}$ & $\begin{array}{l}\mathrm{EC} \\
\left(\mathrm{uScm}^{-1}\right)\end{array}$ & $\begin{array}{l}\mathrm{PO}_{4}{ }^{3-} \\
\mathrm{mg} / \mathrm{L}\end{array}$ & $\begin{array}{l}\mathrm{SO}_{4}{ }^{2-} \\
\mathrm{mg} / \mathrm{L}\end{array}$ & $\begin{array}{l}\mathrm{NO}_{3}{ }^{-} \\
\mathrm{mg} / \mathrm{L}\end{array}$ & $\begin{array}{l}\mathrm{TH} \\
\mathrm{mg} / \mathrm{L}\end{array}$ \\
\hline 1 & & & & & & & & & \\
2 & Gidigbo & WARD1 & 8.18 & 29.30 & 240 & 0.07 & 0.05 & 0.02 & 420.0 \\
3 & & 8.00 & 27.50 & 270 & 0.03 & 0.03 & 0.03 & 248.0 \\
4 & & WARD3 & 8.05 & 29.00 & 110 & 0.07 & 0.04 & 0.02 & 375.0 \\
5 & & WARD4 & 9.02 & 30.01 & 150 & 0.02 & 0.05 & 0.02 & 406.0 \\
6 & Isale-Oba & WARD5 & 7.82 & 28.70 & 100 & 0.03 & 0.06 & 0.02 & 385.0 \\
7 & & WARD6 & 8.00 & 27.40 & 120 & 0.04 & 0.05 & 0.01 & 246.0 \\
8 & & WARD7 & 8.14 & 29.50 & 114 & 0.03 & 0.03 & 0.03 & 408.0 \\
9 & Molete & WARD8 & 9.10 & 30.10 & 390 & 0.03 & 0.05 & 0.02 & 274.0 \\
10 & & WARD9 & 7.04 & 29.30 & 210 & 0.04 & 0.03 & 0.01 & 200.0 \\
11 & Oke-Adan & WARD10 & 8.18 & 28.80 & 150 & 0.03 & 0.01 & 0.02 & 248.0 \\
12 & & WARD11 & 8.01 & 29.70 & 150 & 0.02 & 0.05 & 0.03 & 246.0 \\
13 & & WARD12 & 7.94 & 28.40 & 130 & 0.04 & 0.06 & 0.03 & 218.0 \\
14 & Oke-Oba & WARD13 & 7.80 & 28.60 & 240 & 0.02 & 0.06 & 0.03 & 450.0 \\
15 & & WARD14 & 9.12 & 27.40 & 260 & 0.01 & 0.05 & 0.02 & 408.0 \\
& & WARD15 & 7.09 & 29.00 & 150 & 0.04 & 0.06 & 0.02 & 200.0 \\
& & Mean & 8.10 & 28.55 & 185.60 & 0.04 & 0.05 & 0.02 & 315.47 \\
& & Standard & 0.61 & 0.88 & 80.88 & 0.02 & 0.02 & 0.01 & 92.34 \\
\hline
\end{tabular}

Table 2: Physico-chemical quality of underground water in Iwo during wet season

\begin{tabular}{llllllllll}
\hline $\mathrm{S} / \mathrm{N}$ & $\begin{array}{l}\text { Name of } \\
\text { Quarters }\end{array}$ & WARD & $\mathrm{pH}$ & $\begin{array}{l}\mathrm{Temp} \\
(\mathrm{oC})\end{array}$ & $\begin{array}{l}\mathrm{EC}(\mathrm{uSc} \\
\left.\mathrm{m}^{-1}\right)\end{array}$ & $\begin{array}{l}\mathrm{PO}_{4}{ }^{3-} \\
\mathrm{mg} / \mathrm{L}\end{array}$ & $\begin{array}{l}\mathrm{SO}_{4}{ }^{2-} \\
\mathrm{mg} / \mathrm{L}\end{array}$ & $\begin{array}{l}\mathrm{NO}_{3}{ }^{-} \\
\mathrm{mg} / \mathrm{L}\end{array}$ & $\mathrm{TH} \mathrm{mg/L}$ \\
\hline 1 & & WARD1 & 6.52 & 26.90 & 230 & 0.01 & 0.02 & 0.03 & 420.0 \\
2 & Gidigbo & WARD2 & 6.92 & 26.10 & 270 & 0.01 & 0.05 & 0.02 & 248.0 \\
3 & & WARD3 & 7.10 & 28.50 & 260 & 0.03 & 0.03 & 0.02 & 315.0 \\
4 & & WARD4 & 7.02 & 28.40 & 160 & 0.02 & 0.01 & 0.02 & 406.0 \\
5 & & WARD5 & 7.17 & 28.00 & 90 & 0.02 & 0.03 & 0.02 & 268.0 \\
6 & Isale-Oba & WARD6 & 6.99 & 26.10 & 270 & 0.03 & 0.11 & 0.02 & 385.0 \\
7 & & WARD7 & 7.09 & 26.40 & 230 & 0.01 & 0.04 & 0.02 & 450.0 \\
8 & & WARD8 & 6.50 & 27.90 & 280 & 0.02 & 0.02 & 0.01 & 315.0 \\
9 & \multirow{2}{*}{ olete } & WARD9 & 6.80 & 26.50 & 160 & 0.03 & 0.06 & 0.01 & 450.0 \\
10 & & WARD10 & 7.12 & 28.40 & 270 & 0.02 & 0.02 & 0.02 & 406.0 \\
11 & & WARD11 & 8.17 & 26.90 & 190 & 0.01 & 0.04 & 0.01 & 375.0 \\
12 & \multirow{2}{*}{ Oke-Adan } & WARD12 & 7.13 & 27.90 & 50 & 0.02 & 0.05 & 0.01 & 408.0 \\
13 & & WARD13 & 6.43 & 28.00 & 190 & 0.03 & 0.06 & 0.01 & 248.0 \\
14 & Oke-Oba & WARD14 & 6.90 & 28.40 & 100 & 0.02 & 0.03 & 0.01 & 248.0 \\
15 & & WARD15 & 6.99 & 28.10 & 150 & 0.02 & 0.04 & 0.02 & 420.0 \\
& & Mean & 6.99 & 27.50 & 193.3 & 0.03 & 0.04 & 0.16 & 357.50 \\
& & Standard & 0.41 & 0.91 & 73.84 & 0.05 & 0.02 & 0.01 & 75.99 \\
\hline
\end{tabular}

\section{pH Concentration}

One of the prominent parameters in evaluating water quality is $\mathrm{pH}$ according to Hem (1985). The results showed that $\mathrm{pH}$ values range from 7.04 in WARD 9 to 9.12 in WARD 14 during the dry 
season while it ranges between 6.43 in WARD 13 and 8.17 in WARD 11 during the rainy season. The values were generally high during the dry season than in the wet season (Figure 2). This probably indicates the relevance of dilution due to rainstorm which thins out the $\mathrm{pH}$ concentrations in the well water during the rainy season. By World Health Organization (WHO) (2006) drinking water guideline standard of 7-9.2 for $\mathrm{pH}$ values, the mean values of 6.99 and 8.10 observed in rainy and dry seasons respectively, it indicates that the water is within the level permissible and so, safe for human consumption.

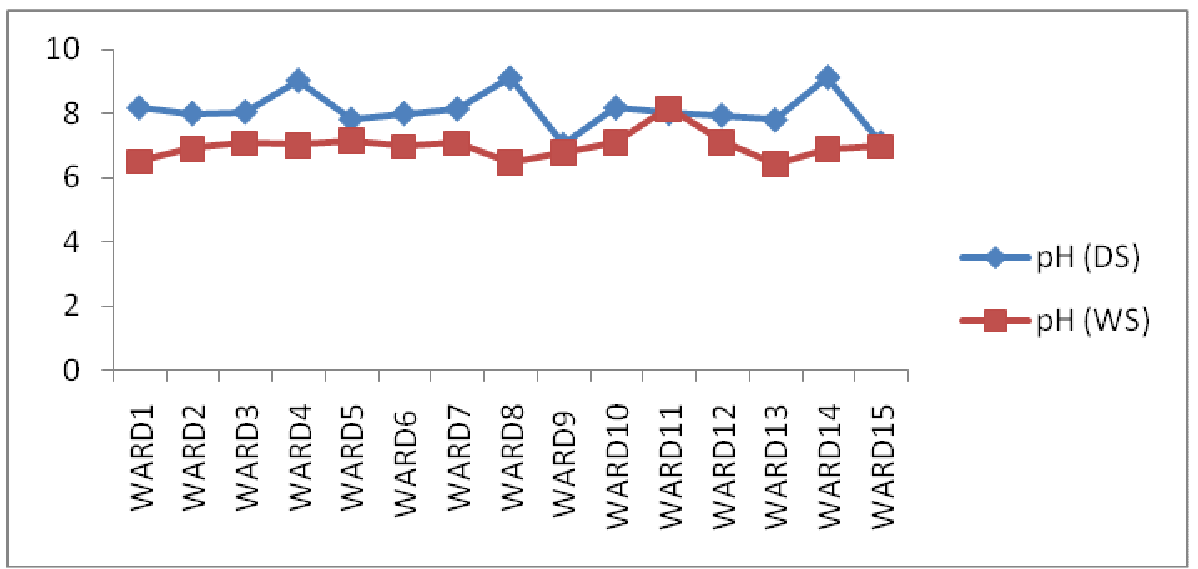

Fig. 2: Seasonal variation in $\mathrm{pH}$

\section{Temperature}

As indicated in Tables 1 and 2, temperature values obtained during the two periods showed higher values during the rainy season than what obtains during the dry season (Figure 3). Ocheri and Ahola (2012) had attributed the similar observation to the ambient environment of the underground water. Determination of water temperature in the well and or boreholes according to Mink (1964) and
Hutton (1983) is a good measure of contamination as it marked effect on bacteria and chemical reaction rates in water. The results showed that the mean temperature is higher during the dry season $\left(28.55^{\circ} \mathrm{C} \mathrm{SD}=0.91\right)$ than in the wet season $\left(27.50^{\circ} \mathrm{C}, \quad \mathrm{SD}=0.88\right)$. However, the mean values for both seasons are still within the permissible standard of $30-40^{\circ} \mathrm{C}$ (WHO, 2006). 


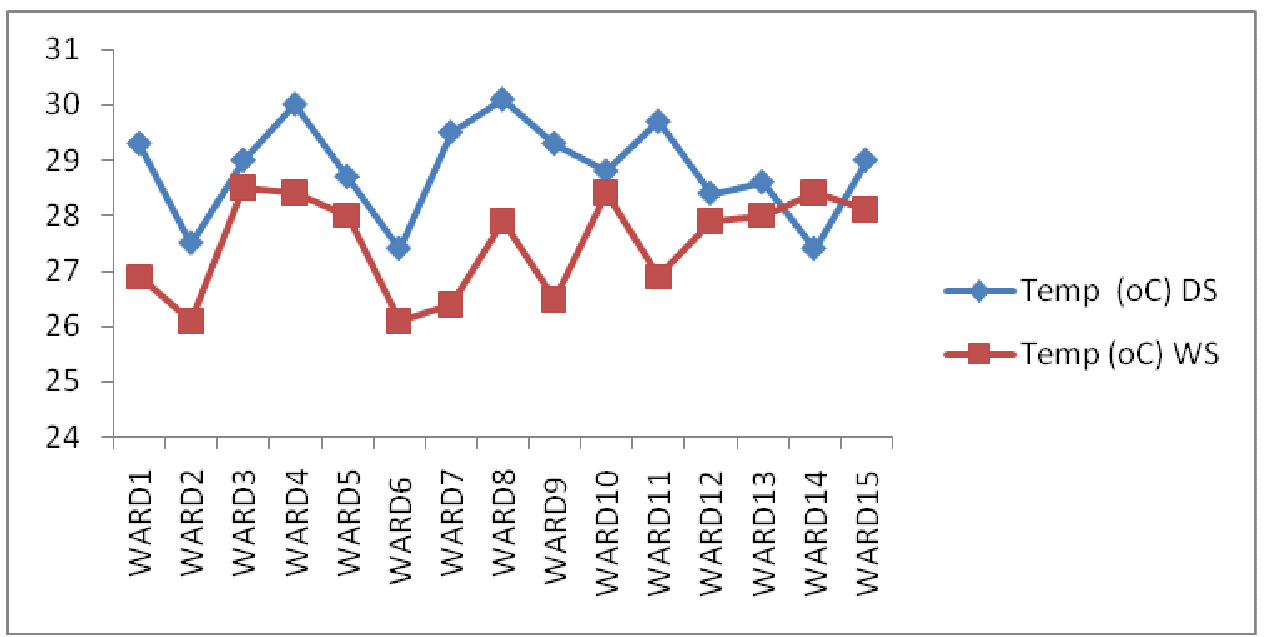

Fig. 3: Seasonal variation in temperature

\section{Electrical Conductivity}

According to Olajire and Imeokparia (2001), electrical conductivity is viewed as a valuable indicator of the amount of dissolved materials in water. The results of the analysis in Tables 1 and 2 showed that electrical conductivity is generally higher during the rainy season than in the dry season. This is attributed to the possible runoff discharge which characterize the rainy season. The result is depicted in Figure 4. The values range from $110\left(\mathrm{uScm}^{-1}\right)$ in WARD 3 to
$390\left(\mathrm{uScm}^{-1}\right)$ in WARD 8 during the dry season while it ranges from $50\left(\mathrm{uScm}^{-1}\right)$ in WARD 12 to $280\left(\mathrm{uScm}^{-1}\right)$ in WARD 8 during the rainy season. However, the mean values of $193.3\left(\mathrm{uScm}^{-1}\right)$ and $185.60\left(\mathrm{uScm}^{-1}\right)$ in both dry and rainy seasons respectively are still within the maximum permissible of $500\left(\mathrm{uScm}^{-1}\right)$ (WHO, 2006) indicating the safety of the water for human consumption. The finding here is similar to that of Ocheri and Ahola (2012).

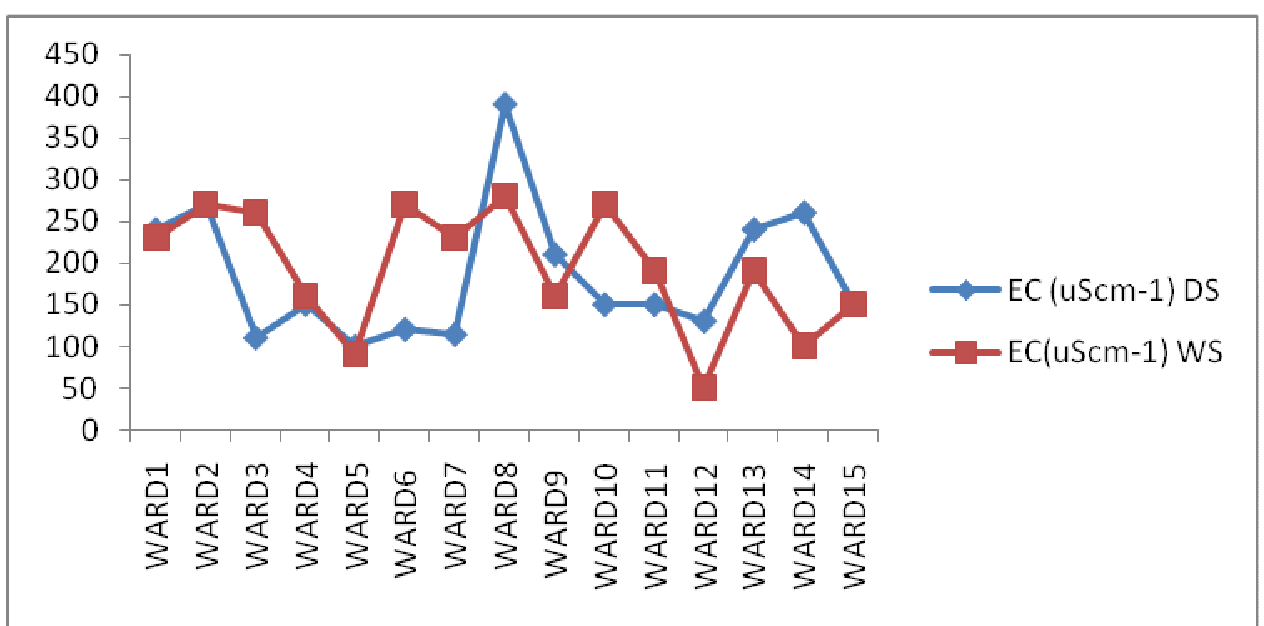

Fig. 4: Seasonal variation in electrical conductivity 
An Assessment of Seasonal Variations in Physico-Chemical Characteristics..................GUNBODE et al.

\section{Phosphate}

Figure 5 showed the pattern of phosphate in the two seasons. The values were generally higher during the dry season than what were obtained during the rainy season as shown in Tables 1 and 2. This is probably the demonstration of underground water dilution process which reduces the concentration of phosphate in the water. The values range from $0.01 \mathrm{mg} / \mathrm{L}$ in WARD 14 to 0.07 $\mathrm{mg} / \mathrm{L}$ in WARD 1 and WARD 3 in the dry season while it spans through 0.01 $\mathrm{mg} / \mathrm{L}$ in WARD 1, WARD 2, WARD 7 and WARD 11 to $0.03 \mathrm{mg} / \mathrm{L}$ in WARD 3, WARD 6, WARD ( and WARD 13. However, the mean concentrations of $0.04 \mathrm{mg} / \mathrm{L}$ and $0.03 \mathrm{mg} / \mathrm{L}$ during the dry and rainy seasons respectively are still within the permissible standard of 50-100 $\mathrm{mg} / \mathrm{L}$ by the WHO (1993). The lower phosphate concentrations could be attributed to the fact that the wells sampled are not within the areas were free from surface wash of chemical fertilizers and the likes whichis one of the major sources of phosphate (Dami et al., 2013)

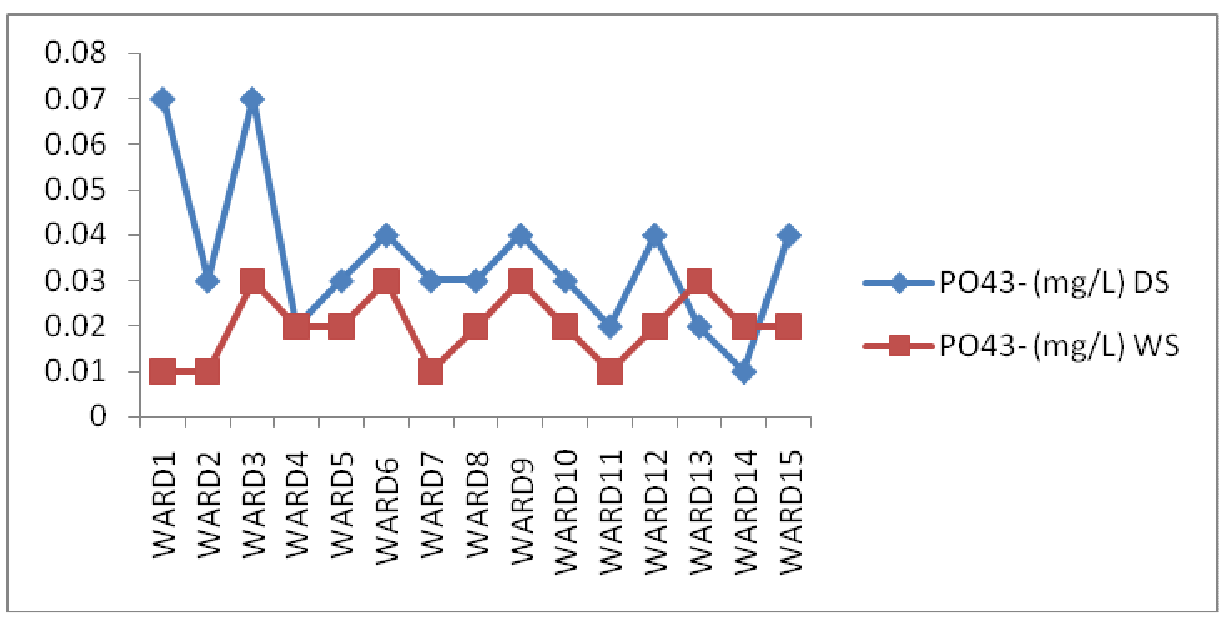

Fig. 5: Seasonal variation in phosphate

\section{Sodium}

The results presented in Table 1 and 2 and depicted in Figure 6 show that sulphate concentration in the underground water was higher during the dry season than in the rainy season. This may equally be attributed to dilution brought about by underground flow into the wells during the rainy season. The mean concentrations in both dry and rainy seasons were respectively 0.05 $\mathrm{mg} / \mathrm{L}$ and $0.04 \mathrm{mg} / \mathrm{L}$. All the values obtained in this work were below the maximum permissible of $100 \mathrm{mg} / \mathrm{L}$ for drinking water by Nigeria Industrial Standard (NIS) (2007). The lower sulphate concentrations in Iwo could be connected to the fact that the wells were not within areas where fertilizers are used (Dami et al., 2013). 


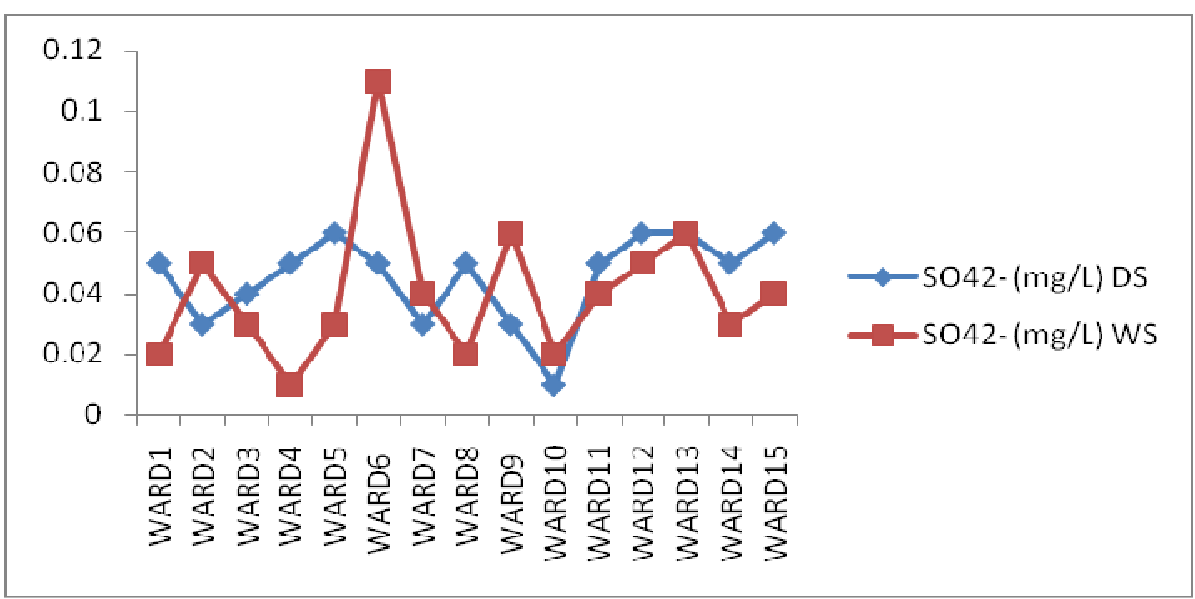

Fig. 6: Seasonal variation in sulphate

\section{Nitrate Concentration}

As revealed in Tables 1 and 2, nitrate concentrations in the well water were generally low in both dry and rainy seasons. This is depicted in Figure 7. The mean concentration of nitrate is 0.01 $\mathrm{mg} / \mathrm{L}$ in both seasons. Nitrate concentration above the recommended value of $10 \mathrm{mg} / \mathrm{L}$ is dangerous to pregnant women and poses a serious health threat to infants less than three to six months of age because of its ability to cause methaemogloinaemia or blue baby syndrome in which blood loses its ability to carry sufficient oxygen (Groen et al., 1988; Adelana, 2006; Ocheri et al., 2010). The well water is safe for man in this regard. However, Dami et al. (2013) noted that low nitrogen concentration in ground water implies that plants and animals that depend on nitrogen would be suffering from nitrogen-deficiency diseases.

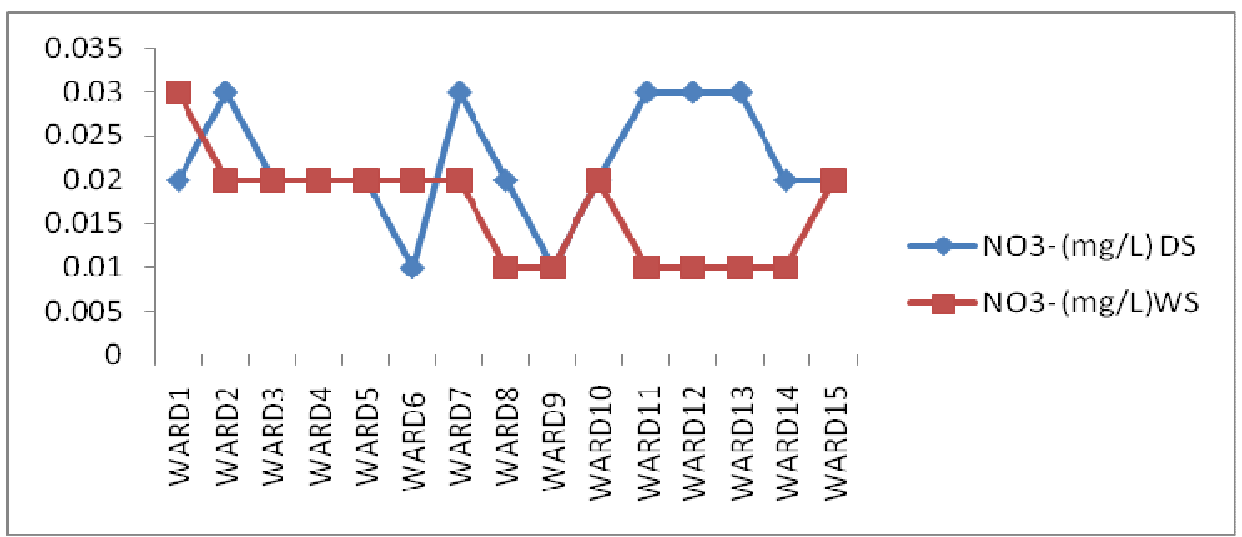

Fig. 7: Seasonal variation in nitrates

\section{Total Hardness}

Figure 8 showed the pattern of the total hardness $(\mathrm{TH})$ of well water in the study area. The results showed a higher mean value of $357.5 \mathrm{mg} / \mathrm{L}$ in the rainy season than the mean value of $315.47 \mathrm{mg} / \mathrm{L}$ obtained in the dry season. Despite of this, the mean values are still 
within the $500 \mathrm{mg} / \mathrm{L}$ maximum permissible by WHO standard. This observation indicates the general safety of the well water in Iwo to human consumption. It is noted in both Table 1 and 2 that the highest $\mathrm{TH}$ value in both dry and rainy seasons is $450 \mathrm{mg} / \mathrm{L}$ in both WARD 7 and WARD 9 during the rainy season which is still below the maximum allowed.

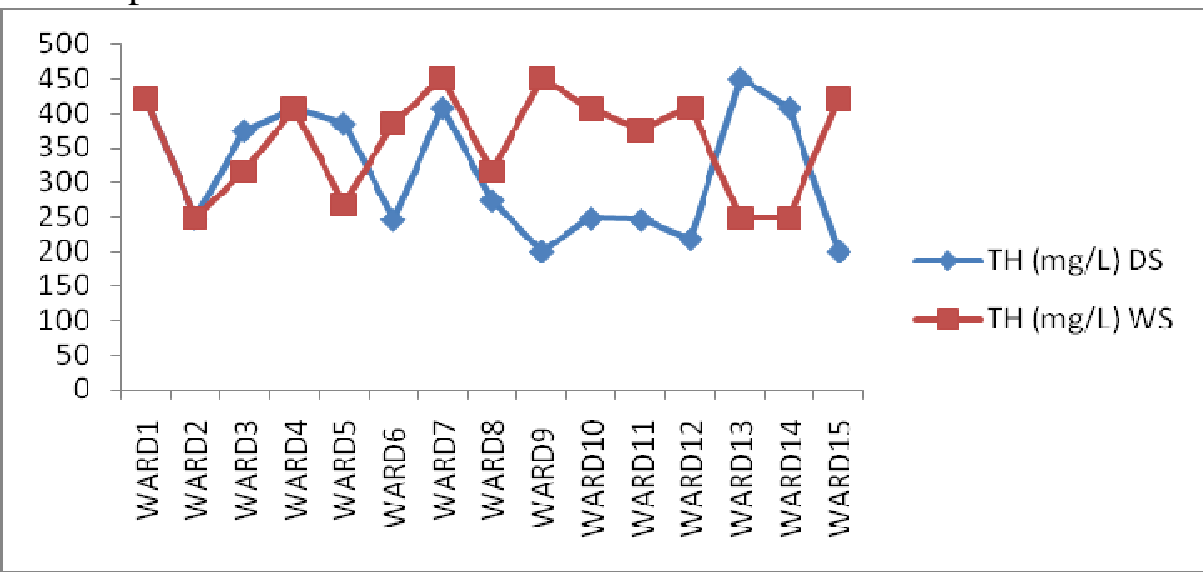

Fig. 8: Seasonal variation in total hardness (TH)

\section{Conclusion}

The seasonal variation in underground water quality in Iwo has been assessed. The results showed that all the quality parameters analysed were within the standard limits according to the World Health Organization (WHO) and Nigerian Industrial Standard (NIS). The results indicate that the well water is safe for human consumption. Also, the status of the groundwater quality in the area of investigation shows that less effort and or resources are required on accessing health-supportive water for home use all year round. However, water resource management should be geared towards maintaining the water quality status through adequate protection of the wells especially by covering them with lids that are free of rusts, regular maintenance of the facilities and particularly, through routine quality assessment of the well water. The results also revealed the susceptibility of the wells investigated to pollutants especially from surface runoff. Thus, management strategy should include public enlightenment on the need to locate wells in the areas that are not prone to wash during rainy season and also, home and industrial effluents. Further studies should consider the assessment of bacteriological constituents of the wells in the study area.

\section{References}

Adelana, S.M.A. (2006). Nitrate pollution of groundwater in Nigeria in $\mathrm{Xu}, \mathrm{Y}$. and Usher, B.(eds.) groundwater pollution in Africa. Taylor and Francis Group, London, pp37-46.

Adelana, S. (2005). G8 Conference of world leaders: A contribution to debate on poverty reduction in subSaharan Africa. International Association of Hydrogeologists.

Ademoroti, C.M.A. (1996a). Standard methods for water and effluent 
analysis. Foludex Press Ltd., Ibadan.

Dami, A., Ayuba, H.K. and Amukali, O. (2013). Groundwater pollution in Okpai and Beneku, Ndokwa East local Government, Delta State, Nigeria. J. Env. Res \& Mgt. 4(1): 0171- 0199.

Groen, J., Schumann, J.B and Gernaer, T.W. (1988). The occurrence of high-nitrate concentration in groundwater in villages in North western, Burkina Fasso. J. Afr. Earth Sci., 7(7/8):988-1009.

Hem, J.D. (1995). Study and interpretation of the chemical characteristics of the natural waters. US Geological Survey, Pages 27-54.

Hutton, L. (1983). Field testing of water in developing countries, Water Resources Centre, Unwin Brothers Limited, Britain.

Ibe, S.N. and Okplenye, J.J. (2005). Bacteriological analysis of borehole water in Uli, Nigeria. Afri. $J$. Applied Zoology \& Env. Biology.7:116-119.

MacDonald, A.J., Davies, R. and Chillon, J. (2005). Developing groundwater. A guide to rural water supply. ITDG Publishing.

Mark, W.R., Ximing, C. and Sarah, A.C. (2002). World water and food to 2025: Dealing with scarcity, International Food Policy Research Institute, NW, Washington DC, USA.

Mink, J.F. (1964). Groundwater temperature in tropical Island environment. J. Geoph. Res. 66: 5230-5250.
Nash, L. (1993). Water quality and health in Gleick, P.H. (ed.) Water crisis. New York, Oxford University Press.

NIS (2007). Nigerian Standard for Drinking water quality. Nigerian Industrial Standard under Standard Organization of Nigeria, Lagos, Nigeria. Pp15-19.

NPC (2006). National Population Commission: The Nigeria Census. Federal Government of Nigeria.

Ocheri, M., Iyange, M. and Obeta, M.C. (2010). Seasonal variation in nitrate levels in hand dug wells in Markurdi Metropolis. Pakistan J. Nutrition, 9(6): 539-542.

Olajire, A.A. and Imeokpania, F.E. (2001). Water quality of Osun River: Studies on inorganic nutrient.

Environmental Monitoring and Assessment. 69:17-28.

Ocheri, M.I. and Ahola, O. (2012). Seasonal variation in physicochemical characteristics of rural groundwater of Benue State, Nigeria. J. Asian Sci. Res., 2(10): 574-586.

United Nations (1997). Commission for sustainable development. Comprehensive assessment of the fresh water resources of the world, New York.

WHO (2006) Guidelines for Drinking Water. First addendum to $3^{\text {rd }}$ edition, Vol. 1 Recommendations, Geneva.

WHO (1993). World Health Organization Guidelines for Drinking water. $3^{\text {rd }}$ Edition. Geneva, Switzerland. Pp4162.

Yakubu, S. (2013). Assessment of Water quality of hand-dug wells in Zaria LGA of Kaduna State, Nigeria, Int. J. Eng. \& Sci., 2(11):01-04. 